Cahiers $d u$ MONDE RUSSE

\section{Cahiers du monde russe}

Russie - Empire russe - Union soviétique et États indépendants

\title{
Repression of Kazakh Intellectuals as a Sign of Weakness of Russian Imperial Rule
}

The paradoxical impact of Governor A.N. Troinitskii on the Kazakh national movement*

La répression des intellectuels kazakhs ou la faiblesse de l'administration directe russe :l'impact paradoxal du gouverneur A.N. Trojnickij sur le mouvement national kazakh

\section{Tomohiko Uyama}

\section{OpenEdition}

\section{Journals}

\section{Electronic version}

URL: http://journals.openedition.org/monderusse/8216

DOI: $10.4000 /$ monderusse. 8216

ISSN: $1777-5388$

\section{Publisher}

Éditions de l'EHESS

\section{Printed version}

Date of publication: 1 October 2015

Number of pages: 681-703

ISBN: 978-2-7132-2507-9

ISSN: $1252-6576$

\section{Electronic reference}

Tomohiko Uyama, «Repression of Kazakh Intellectuals as a Sign of Weakness of Russian Imperial Rule », Cahiers du monde russe [Online], 56/4 | 2015, Online since 01 October 2018, Connection on 24 April 2019. URL : http://journals.openedition.org/monderusse/8216 ; DOI : 10.4000/monderusse.8216

This text was automatically generated on 24 April 2019

(C) École des hautes études en sciences sociales 


\title{
Repression of Kazakh Intellectuals as a Sign of Weakness of Russian Imperial Rule
}

\author{
The paradoxical impact of Governor A.N. Troinitskii on the Kazakh \\ national movement* \\ La répression des intellectuels kazakhs ou la faiblesse de l'administration directe \\ russe : l'impact paradoxal du gouverneur A.N. Trojnickij sur le mouvement \\ national kazakh
}

Tomohiko Uyama

1 Although bureaucracy as an ideal type in Max Weber's concept is a form of impersonal rule, the personality of individual bureaucrats often influences the actual handling of administrative matters. While this holds true for today's developed countries, it held particularly so for tsarist Russia. In the Russian Empire's regions, governors-general and governors, entrusted by the will of the emperor to guard the inviolability of the autocracy's sovereign rights, ${ }^{1}$ held discretionary administrative and judicial powers. They themselves often tried to carry out policies marked by their individuality. In the history of Russian Central Asia, it is well known that Konstantin von Kaufman, the first governor-general of Turkestan (1867-1882), dubbed "half-tsar" by the local population, behaved as a highly authoritarian, patriarchic and at the same time enlightening ruler, while his successor Mikhail Cherniaev (1882-1884) tried in vain to negate everything Kaufman did. $^{2}$ One may suppose that this kind of situation occurred typically right after the conquest and administration became more systematized later, but this paper demonstrates that personal factors in regional administration of Central Asia were still strong in the last years of tsarism, although of a different character than in the Kaufman era.

2 Among the objects of power exercised by governors were political and social activists, whose ranks mainly included intellectuals. ${ }^{3}$ Studying the history of the Kazakh intelligentsia, we noticed that a number of prominent intellectuals who later became 
leaders of the national movement, such as Akhmet Baytŭrsïnov (1873-1937), Yaqub Aqbaev (1876-1934), Kölbay Tögísov (1879-1919), and Mir-Yaqub Dulatov (1885-1935), were arrested in Semipalatinsk oblast around 1910. While persecution of Kazakh activists took place in various regions after the Revolution of 1905, it took an especially harsh character in this oblast. When searching the reasons for this phenomenon, we came across a unique person, Governor Aleksandr Troinitskii. ${ }^{4}$

tskii was born in 1869 to an aristocratic family of elite officials. His father, Nikolai Aleksandrovich Troinitskii (1842-1913), after working as governor in Viatka and Riazan provinces, served as director of the central statistical committee and chairman of the statistical council at the Ministry of the Interior. He is known to historians as the editor of the volumes resulting from the first (and only) Russian Empire Census of 1897. Grandfather Aleksandr Grigor'evich Troinitskii (1807-1871) was also a famous statistician who played a leading role in the development and reorganization of statistical agencies during Russia's Great Reforms, and served as deputy minister of the Interior. ${ }^{5}$ As Don Rowney argues, statistics was one of the most important instruments of legibility (the modern state's detailed grasp of the social, demographic and economic characteristics of the societies which it serves or rules) that were becoming available to the tsarist state, and statistical agencies expanded proportionately to the need to gather accurate and comprehensive information on commerce and agriculture. ${ }^{6}$ Troinitskii's father and grandfather were thus among the bureaucrats who played a crucial part in the modernization of the tsarist state.

Aleksandr Nikolaevich Troinitskii (1869- ?) himself entered the Ministry of the Interior after graduating from the Imperial School of Jurisprudence in 1891 and served at various positions in Olonets, Chernigov, Orël, and Stavropol' provinces, as well as at the land department (zemskii otdel) of the ministry, where he participated in the work on the 1897 census. $^{7}$ He became vice-governor of Tobol'sk province in May 1902, and governor of Semipalatinsk oblast in April 1908. ${ }^{8}$ Earlier, the governors of Aqmola (Akmolinsk), Semipalatinsk, and Torghay (Turgai) oblasts were called military governors, and army generals and officers were appointed to these posts. But an amendment to the statute for the administration of the Steppe oblasts in 1908 changed these military governorships to ordinary ones, and Troinitskii became the first civilian to work as Semipalatinsk governor. ${ }^{9}$ The change from military to civilian rule might seem to indicate relaxation of control, but the fact was the opposite.

5 Troinitskii's tenure in Semipalatinsk coincided with a crucial period of the political and cultural history of Kazakhstan. While prominent Russian-educated Kazakh intellectuals first appeared as early as the mid-nineteenth century (most notably, Shoqan Wälikhanov and Ibrahim Altïnsarin), and the stratum of culturally active intellectuals was formed toward the end of the century, ${ }^{10}$ it was during the Revolution of 1905 that Kazakhs began their political activities in earnest. They organized demonstrations and rallies in various cities and towns, and among others, the rally of June 1905 in Qarqaraly (Semipalatinsk oblast) adopted a petition, signed by 12,767 people, criticizing the government's interference into religious affairs and the policy of Russification and colonization. ${ }^{11} \mathrm{~A}$ number of intellectuals, including the future leader of the Alash Orda autonomous government, Älikhan Bökeykhanov (1866 ?-1937), were elected to the First and Second State Dumas. In June 1907, however, the Kazakhs and other Central Asians were deprived of voting rights to the State Duma, and the Russian authorities strengthened pressure on political activists. Kazakh intellectuals temporarily waned, but soon revitalized their 
cultural and social activities with political connotations : the number of books in Kazakh rapidly grew, ${ }^{12}$ and the magazine Ay-qap (1911-1915) and the newspaper Qazaq (1913-1918) began to be published. How did Troinitskii's oppressive policy react to and influence this renewed surge of Kazakh intellectuals' activities, which eventually developed into the autonomous movement of 1917 ?

In this paper, we begin by describing the repression of Kazakh intellectuals under Troinitskii and their reactions. Then we scrutinize Troinitskii's ideas, perceptions, and personality through his official reports and personal letters. Through these examinations, we aim at elucidating the mechanism of repression, in which personal and systemic factors intertwined and which reflected generally segregated but partly collusive relations between the Russian bureaucracy and Kazakh society. Finally, the paper demonstrates the paradoxical effects of repression on the Kazakh national movement.

7 As other papers of this volume show, studies of Kazakh officials have recently been developing, but curiously enough, researchers still know little about Russian higher officials in the Kazakh Steppe, and this paper aims at filling this blank. We also use sources related to Troinitskii's previous workplace, Tobol'sk province, both because his experiences there are important for understanding his activities in Semipalatinsk, and the administrative institutions and practices in the Kazakh Steppe were closely related to those of Siberia - unofficially, Aqmola and Semipalatinsk oblasts were often called Siberia. This paper is an attempt to connect the history of the Kazakh Steppe with Siberian and Russian imperial history, at the same time underlining the agency of Kazakhs themselves.

\section{The case of Aqbaev : The persecuting governor and the petitioning intellectual}

8 The first major case of repression was that of Yaqub Aqbaev, a lawyer who graduated from the faculty of law of St. Petersburg University in 1903 and worked at the Omsk appellate court (sudebnaia palata) and other judicial organs until his resignation in November 1905. During the 1905 Revolution, he actively participated in demonstrations and writing petitions to the tsar and the government, including the above-mentioned Qarqaraly petition. He especially became famous by his enthusiastic speeches at rallies in Pavlodar and Qarqaraly in November. After being arrested but acquitted in 1906, he worked as an assistant attorney (pomoshchnik prisiazhnogo poverennogo), writing solicitations and complaints to the authorities on behalf of local residents. ${ }^{13}$

In November 1908, Troinitskii wrote to the governor-general of the Steppe, Evgenii Shmit, ${ }^{14}$ that Aqbaev, appealing to people for disobedience to power, behaved like a mini-tsar (tsarëk) of the steppe, which could be seen as a sign of weakness of power to the "semi-barbaric" inhabitants and was especially dangerous for a region bordering China. He asked the governor-general to banish Aqbaev to a remote corner of Aqmola oblast and then to request the minister of the Interior to banish him to a faraway province in Siberia for five years. Responding to this request, the governor-general banished Aqbaev to Omsk uezd (district) in Aqmola oblast (not a remote place, actually) and asked the minister to further banish him to Yakut oblast. The minister, however, decided to let him live under surveillance in a place he selected except St. Petersburg, Moscow and the capital provinces as well as the Governor-Generalship of the Steppe 
(Semipalatinsk and Aqmola oblasts) for two years. Aqbaev left Omsk in February 1909 and headed to Qapal in Semirech'e oblast. ${ }^{15}$ This means that he went to a Kazakh town much closer to the Chinese border than his native Qarqaraly, despite Troinitskii's argument about the danger of his presence in a border region.

Versed in Russian law and with high political awareness, Aqbaev was not silent. Just then, an inspection was going on led by Count Pahlen for the purpose of reforming the administration of the Turkestan region including Semirech'e ${ }^{16}$ and Aqbaev sent Pahlen a long petition of seventy-three pages in April $1909 .{ }^{17}$ He thought that he had been banished because of secret denunciations by local officials, including a former peasant captain (krest'ianskii nachal'nik - see below about this position) - Tsylov, a tax inspector - Panfilov, a former interpreter for the uezd police office - Bekmetev, the secretary of the uezd peasant captains' conference - Chanchikov, and a number of volost (canton) heads, who resented his exposure of their wrongdoings. Aqbaev described their corruption and dissolute life in detail, in a garrulous manner. He specifically pointed out systemic corruption related to elections of volost heads : candidates (Kazakhs) bribed the peasant captain (usually a Russian) and his companions, and they together manipulated the numbers of voters and vote results. ${ }^{18}$

Aqbaev also believed that Troinitskii used the secret denunciations only as a pretext and that the real reasons for the banishment were his complaint against Filippov, whom Troinitskii invited from Tobol'sk province to the post of peasant captain as the successor to fired Tsylov, ${ }^{19}$ as well as Aqbaev's political influence in local society. He noted insightfully that if the Semipalatinsk governor had been General Galkin (Troinitskii's predecessor), ${ }^{20}$ he would have lived peacefully at home and would not have dreamt of becoming a candidate for exile to Yakut oblast. He sarcastically noted that it was clear that he had fallen victim to a "fetishistic" need for maintaining the prestige of power.

The petition, which Aqbaev wrote with abundant vocabulary and such extravagant expressions as "believing in the ultimate triumph of the moral unity of humankind on the basis of the teachings of Jesus Christ" (although he was apparently a Muslim) in order to appeal to the sense of justice of the Russian state, proved ineffective. Semipalatinsk oblast was not an object of Pahlen's inspection, and the petition was forwarded and entrusted for handling to Troinitskii through the governor-general of the Steppe. Troinitskii sent inquiries to the officials named in Aqbaev's petition, who naturally denied the accusations. It is noteworthy, however, that Kamenshchikov, a former chief of Qarqaraly uezd, confessed that Abdul-Azii Bekmetev - the police interpreter who was a relative of Aqbaev's wife and whom Aqbaev named as one of his slanderers - was his secret agent. Bekmetev, a member of a reputed Tatar merchant family in Qarqaraly, was formally a sympathizer of the Constitutional Democratic Party (Kadets), but fearful of being banished by the uezd chief, became his agent and began to provide information against Aqbaev. ${ }^{21}$ Here we can observe how officials exploited complex human relationships in local society and fear of oppression to collect information and frame up politically troublesome people.

13 Aqbaev and his family did not give up. From the beginning, his mother and wife petitioned to the governor-general not to banish him, the only breadwinner of the family and a sick person, to no avail. ${ }^{22}$ When Aqbaev was banished to Omsk uezd, they wrote to Aqmola governor that he had been victimized by false denunciation by Kazakhs supported by some chief officials, arguing, "Your Excellency knows the morals of steppe Kazakhs down to the smallest details and the value of their denunciations and slanders."23 
Later, the mother seems to have written directly to the Ministry of the Interior that she was fatally ill, and in October 1909, Acting Governor-General Tikhmenev (in Shmit's absence) asked the Semirech'e governor to release Aqbaev temporarily. However, Troinitskii wrote to Shmit that Aqbaev's coming to Qarqaraly was highly undesirable as he had not ceased anti-government activities, and that his mother was simply fat and had no fatal illness. Shmit canceled the release and Troinitskii sent Aqbaev, who had already arrived in Qarqaraly, back to Qapal. ${ }^{24}$

In January 1910, receiving Aqbaev's own petition, the chief of Qapal uezd interceded for shortening the period of his banishment, arguing that his behavior was impeccable, and the Semirech'e military governor supported this ${ }^{25}$ Nevertheless, in February the same year, the minister of the Interior prohibited nine Kazakhs including Aqbaev from residing in the Governor-Generalship of the Steppe and Semirech'e and Torghay oblasts for two years. ${ }^{26}$ This can be regarded as Troinitskii's partial victory : Aqbaev went to Troitsk in Orenburg province, now far from Chinese borders but still adjacent to the Kazakh Steppe. 27

\section{The cases of Baytŭrsïnov, Tögísov, and Dulatov : Different interactions and different results}

15 When Aqbaev was still in the middle of his struggle for returning home, in July 1909 , another prominent intellectual, Akhmet Baytŭrsïnov was arrested in Qarqaraly. A poet and former school principal, he was accused of anti-government agitation and separatism. His wife wrote to the governor-general of the Steppe that he must have been arrested on the basis of false information given to the authorities by Kazakhs motivated by factional feud, and asked the governor-general to put her husband on trial promptly if he was a criminal, otherwise release him. Troinitskii, however, objected to the release. Baytŭrsïnov's alleged wrongdoings, enumerated by the governor, were the following: he had launched a campaign for the return of Aqbaev; he propagated the idea of autonomy, claiming that China and Afghanistan would support Kazakhs if they stood up; he told Kazakhs that Russians were not worth fearing, as only Cossacks had remained loyal to the tsar; he instigated people not to pay taxes; he tried to instill hostility between the Russians and the Kazakhs. ${ }^{28}$

Calls for Baytŭrsïnov's release spread to the imperial capital in November, with State Duma deputy Nikolai Skalozubov (1861-1915) ${ }^{29}$ appealing to the Ministry of the Interior, and Sovremennoe slovo, A newspaper close to the Constitutional Democratic Party, publishing an article "Kazakh national poet in prison" (Kirgizskii narodnyi poet v tiur 'me). ${ }^{30}$ All these appeals were in vain, and after sitting in jail without being indicted until February 1910, Baytŭrsïnov, like Aqbaev, was prohibited from residing in the Steppe oblasts and settled in Orenburg.

In Ust-Kamenogorsk uezd, situated in the eastern part of Semipalatinsk oblast, Kölbay Tögísov (figuring in Russian sources as Telengutov) was arrested in August 1909. He was an unlicensed lawyer and former interpreter and secretary of justices of the peace in neighboring Zaysan uezd, and had joined the demonstrations in Qarqaraly in 1905 together with Aqbaev, Baytŭrsïnov and others. After the arrest, Tögísov and his wife immediately petitioned to Shmit, the governor-general of the Steppe, for his release. He surmised that the chief of Zaysan uezd had asked the chief of Ust-Kamenogorsk uezd to 
arrest him in revenge for the dismissal of Chernavin, a peasant captain against whom Tögísov had brought a charge to the governor-general. ${ }^{31}$

Troinitskii, in the meantime, wrote to Shmit that Tögísov, connected with "extreme-left parties" and reputed as an influential and omnipotent man among the "dark masses," had committed crimes such as instigation of land disputes and non-payment of taxes, obstruction to settlement of Russian migrant peasants and sedentarization of Kazakh nomads, and applications for Chinese citizenship. In evidence of Tögísov's threat to social order, Troinitskii referred to the resolutions of Kazakh and Cossack residents to deport him. Practically accusing Shmit, Troinitskii also noted that Tögísov's prestige had especially increased after the governor-general fired Chernavin in response to his complaint. Emphasizing the dangers Tögísov could cause in the oblast bordering China, including even the possibility of an armed revolt of Kazakhs, Troinitskii asked Shmit to request the minister of the Interior to exile him to Yakut oblast for five years, as banishment to Semirech'e or Aqmola oblast was useless (he probably had in mind Aqbaev's case). ${ }^{32}$

Troinitskii apparently expected that his enumeration of Tögísov's activities that posed a threat to Russian rule, security, and the prioritized policy of Russian peasant resettlement would be convincing for higher officials but he was mistaken this time. The governor-general of the Steppe ordered Tögísov's release in November 1909 on the grounds that the case was dismissed for lack of evidence. The order was apparently issued pursuant to a petition that a Cossack sent to the minister of the Interior. This Cossack was one of the initiators of a village meeting resolution that Tögísov be deported - a resolution that Troinitskii used as a key argument for his banishment. However, the Cossack asked the minister to invalidate the resolution because he had been deceived by the peasant captain Kholmskii, who boasted that he could easily influence his friend's, Troinitskii's, judgment - a friend with whom he had worked and drunk in the past. Tögísov, in turn, also sent a petition to the minister of the Interior in which he suggested that Troinitskii's judgment was biased, stating that if the latter and Kholmskii were indeed good friends, "I do not expect any mercy from Mr. Troinitskii. Therefore I humbly ask Your Excellency to immediately deport me from Semipalatinsk oblast," and repeated, "I am not guilty." Troinitskii asserted that the Cossack and Tögísov had teamed up in the prison where they both sat, but could not change the governor-general's order. ${ }^{33}$ Tögísov was arrested and jailed some time later, and in July 1912, one month before the end of his prison term, the question arose as to where he should reside after his release. Tögísov wanted to live in Qapal. Troinitskii pointed out that Qapal was connected with Semipalatinsk oblast by roads - and that Aqbaev had returned to Qarqaraly from Qapal unnoticed by the police, and requested the governor-general of the Steppe to banish Tögísov to Yakut oblast, or at least to Yenisei province, for five years. Shmit refused, referring to Interior Ministry circulars of 1909 and 1911 limiting administrative exile to exceptional cases, and allowed Tögísov to live in Qapal. ${ }^{34}$

21 Mir-Yaqub Dulatov was arrested later than the above-mentioned three, in June 1911, on the charge of inciting discontent with the government among the Kazakh population and of lese-majesty in his collection of poems, Awake, Kazakh ! ${ }^{35}$ Although he lived in Petropavlovsk in Aqmola oblast, he was arrested in Semipalatinsk when he visited the city. The arrest was carried out by Levanevskii, assistant chief of the Omsk Gendarme Directorate (who resided in Semipalatinsk), following an information by the chief of Qarqaraly uezd about the book's circulation among the Kazakhs in the uezd. ${ }^{36}$ According 
to Troinitskii and Levanevskii, an interpreter at the governor-general's chancellery had earlier found this book legitimate ${ }^{37}$ thereby accusing the Semipalatinsk governor's interpreters of producing a biased and distorted translation, but the Kazan Provisional Committee on the Press banned the book, recognizing it criminal. Dulatov was let out on bail and returned to Petropavlovsk, but Troinitskii sent him back to Semipalatinsk. ${ }^{38}$

Although the above-mentioned episode on the collision between interpreters suggests that Troinitskii and his subordinates began to view Awake, Kazakh ! as a criminal book earlier than others, there is no evidence of the governor's further effort to severely punish Dulatov, probably because the latter, non-resident of Semipalatinsk oblast, was not entangled in local intrigues and secret denunciations. However, because of his book's huge influence and resonance among the Kazakhs, Dulatov could not escape persecution. He was convicted in court, and after being released from prison in 1912, lived in Orenburg. There he and Baytŭrsïnov launched the newspaper Qazaq in cooperation with Bökeykhanov, who had also been prohibited from living in the Steppe oblasts and resided in Samara. ${ }^{39}$

These four cases of repression demonstrate Troinitskii's habit of detaining Kazakh intellectuals for a long time without trial and of trying to banish them to remote places like Yakut oblast. Political oppression was common in the Russian Empire, and the governor-general of the Steppe supported Troinitskii at the beginning, but gradually became aware that many of his requests were excessive and unfounded, and often connected with the interests of his henchmen. The Ministry of the Interior also reacted with caution, although Troinitskii did not stop seeking to inflict harsh punishments. Kazakh intellectuals and their families actively petitioned to the authorities and sometimes could win some officials' sympathy. They commonly argued that the arrests were based on false information (even appealing to officials' stereotyped notion about the Kazakhs' inclination to factional strife and slander), and noted Troinitskii's key role in oppression. People he targeted could not entirely escape oppression, but there were also legal mechanisms and human factors that mitigated it to some extent.

\section{Entanglement of bureaucracy and Kazakh society, and Troinitskii's experiences in Tobol'sk}

Complicated processes and different results of the persecution of Kazakh intellectuals reflected the characteristics of bureaucratism in late imperial Russia. On one hand, there still remained ample scope for administrative discretion. As Jane Burbank puts it, the "manipulation of rights was a foundation of Russian administrative practice and a characteristic behavior of even humble bureaucrats," ${ }^{40}$ and satisfaction or rejection of petitions (a major tool in Russia for the rulers to learn the needs of the people and for the ruled to address grievances ${ }^{41}$ ) much depended on individual officials, so Troinitskii could strongly affect the fates of the inhabitants of the oblast. On the other hand, final decisions on more or less important matters needed approval of higher officials (in this case, the governor-general) and the central office of the ministry. Bureaucratic principles of procedure (not necessarily corresponding to principles of rule of law) and collective common sense could sometimes prevent unfounded or unlawful persecutions.

Dependence of the level of persecutions on the individual characters of the governors, and especially the stark change that occurred when Troinitskii replaced Galkin (as 
Aqbaev suggested), can be confirmed by other sources. An ethnographer and deputy of the First and Second State Dumas elected from Semipalatinsk oblast, Nikolai Konshin (1864-1937) noted differences among previous military governors of Semipalatinsk oblast in his memoirs written in the Soviet period: Aleksandr Protsenko (1878-1883) was liberal by the then standards, and under him and Vasilii Tseklinskii (1883-1887), the treatment of exiles was much softer than in other areas of Siberia. The treatment was especially harsh under Orest Shchetinin (1887-1891) and Ivan Sokolovskii (1901-1903), but even compared to them, Troinitskii treated exiles "with extreme hatred." In contrast, Konshin remarked, Galkin was liberal, disliked gendarmes, and often mitigated oppression. ${ }^{42}$

The chief of the Omsk directorate of gendarmerie Ielita-fon-Vol'skii's report to the police department of the Ministry of the Interior in 1907 testifies Konshin's observation :

Galkin, playing for popularity and flirting with revolutionaries, as I am deeply convinced, by no means embodies the firm monarchical power, and unwittingly, without being aware of it, promotes the development of the revolutionary movement in Semipalatinsk. He once told me with conviction that there was no reason to persecute organizers of strikes [... and] that the Corps of Gendarmes was a superfluous organ in Russia costing much money. All this taken together hampers the work of my assistant in the city of Semipalatinsk, Captain Levanevskii. ${ }^{43}$

Later, during the revolt of 1916, Galkin as Syrdarya military governor took a soft line towards the Muslim population, opposing the plan to defend ethnic Russian villages by military units and denouncing violence of a punitive detachment, and was soon sacked by the Turkestan governor-general, Aleksei Kuropatkin. ${ }^{44}$

Konshin also noted that in contrast to Galkin, Troinitskii had been known as an "enemy of liberation movements" since his tenure as vice-governor of Tobol'sk province, ${ }^{45}$ and cracked down not only on Kazakhs but also on liberals among Russian former exiles in Semipalatinsk oblast. For example, enraged at seeing a curtain with the inscription "Long live liberty" and quotations from the October Manifesto in the people's house of Ust-Kamenogorsk, Troinitskii ordered the police to burn the curtain and branded the city as a nest of revolutionaries in his explanatory note to the police department of the Ministry of the Interior, although Governor-General Shmit pointed out the absence of facts proving Troinitskii's assertion. Numerous police officers he brought from Tobol'sk to Semipalatinsk framed up innocent people and engaged in bribery, torture and rape ; this was especially the case in the investigation department (sysknoe otdelenie) opened in 1909 by Troinitskii's efforts. Vice-governor Grigorii Abaza investigated the offenses despite obstructions, and the police officers were put on trial and sentenced to imprisonment. Konshin also referred to Troinitskii's abomination during drinking and his relations with women. ${ }^{46}$

As petitions of persecuted Kazakh intellectuals show, the police often used secret denunciations by local people, whose motives were entangled with complex human relations in Kazakh society aggravated by elections. The institution of popularly elected heads of volosts and villages as well as judges in customary courts was introduced in Central Asia in the late 1860s, on the model of a similar institution introduced in Russian rural areas some years earlier by the Great Reforms, but elections soon became the venue of factional strife and vote buying. ${ }^{47}$

Remarkably, petitions of Aqbaev and Tögísov suggest that corruption in elections deeply involved Russian officials, especially peasant captains. The institution of peasant captains was an analogue of land captains (zemskii nachal'nik), established in European Russia in 
1889 to supervise rural administration and judiciary in an uchastok (subdivision of an uezd). Peasant captains, introduced in Siberia in 1898, had broader administrative although narrower judicial - powers (and more opportunities for corruption) than land captains, and substantially undermined peasant self-administration. In ethnically mixed areas, they supervised both natives and Russians (including a large number of new immigrants), reflecting the aim of this institution to unify the ethnically divided administrative systems and to promote Russification (obrusenie) and colonization. ${ }^{48}$ Maksim Taube, the governor-general of the Steppe, repeatedly requested the tsar in his annual reports for 1897, 1898, and 1899 to extend the institution of land captains to the Steppe oblasts, ${ }^{49}$ and peasant captains were finally introduced in Aqmola, Semipalatinsk, Torghay, and Ural'sk oblasts in 1902.

31 The system of appointment of land captains from among the local nobility was not applicable to peasant captains because of the lack of landed nobility in Siberia and the Kazakh Steppe. While in Western Siberia the majority of the peasant captains were former officials for peasant affairs (chinovnik po krest'ianskim delam) and presumably knew the region well, many of the peasant captains in Eastern Siberia came from European Russia, often to make easy money or to escape from debt. ${ }^{50}$ Although we do not have collective biographical data of peasant captains in the Steppe oblasts, we can well assume that the situation was similar to Eastern Siberia due to the absence of former officials for peasant affairs (except Aqmola oblast, where this position was introduced in $1894^{51}$ ). According to Aqbaev, the peasant captain Tsylov was a former officer of the St. Petersburg river police, ${ }^{52}$ and Tögísov's petition suggests that the peasant captain Kholmskii had worked with Troinitskii in Tobol'sk or some other place. It is easy to imagine that Troinitskii's use of people with material interests but few knowledge of the region as his agents in localities aggravated corruption and mismanagement.

Troinitskii was a strong advocate of the institution of peasant captains even before coming to Semipalatinsk. When local committees under the Special Conference on the Needs of Agricultural Industry were organized almost all over the Russian Empire by the initiative of Finance Minister Sergei Witte in 1902-1903, the Tobol'sk province committee recommended, among others, introduction of zemstvos (local self-government bodies) and a halt of peasant captains' interference in economic and agricultural activities of rural communities. Officials and experts pointed out that many peasant captains were not versed in agricultural management and their interference damaged initiatives of peasants and rural communities, and that the work of peasant captains depended too much on their individual zeal and preferences, without guarantee of continuity of their undertakings after personnel changes. However, Troinitskii dissented, writing that zemstvos were not suitable to Tobol'sk province, where peasants were illiterate and underdeveloped, and would be dominated by wealthy peasants and extortioners (kulaki i miroedy) ; land and peasant captains, possessing firm power and being close to the people, had a mission to take care of peasants, who had been deprived of the landlords' care after the Emancipation Reform of 1861 and left prey of extortioners. He claimed that land captains were useful even for highly developed peasants in Stavropol' province, where he worked previously. ${ }^{53}$ Judging from the digest of the local committees' works by the statistician Aleksandr Kaufman, Troinitskii's opinion on these two issues were minor not only in Tobol'sk province but in the whole Siberia. ${ }^{54}$

Troinitskii's reliance on coercion seems to have been strengthened by his experiences in Tobol'sk province during the Revolution of 1905. At that time, due to the illness of 
Governor Aleksandr Lappo-Starzhenetskii, Troinitskii had to cope with demonstrations, strikes, and peasant and prison disturbances as acting governor, and was also appointed acting temporary governor-general in four uezds of the oblast where martial law was imposed in December $1905 .{ }^{55} \mathrm{He}$ strongly relied on coercion and repeatedly asked the army for permission to use local military units and dispatch of new troops, expressing his intention of "vigorous suppression of the riots that are disturbing the entire city under my personal leadership." After the new governor, Nikolai Gondatti, ${ }^{56}$ arrived in April 1906, Troinitskii continued efforts to suppress disorder under the governor's direction. ${ }^{57}$

\section{Troinitskii's ideas, perceptions, and emotions seen from his reports and letters}

was also linked with his distrust of the Kazakhs, an "insidious and hostile people." According to him, they tended to take sides with winners in international conflicts as observed during the Russo-Japanese War, ${ }^{58}$ had repeatedly migrated between Russia and China, and were totally untrustworthy as inhabitants of border regions. He thought that the situation would completely change if a solid network of Russian villages, whose residents would carefully monitor the movement of enemy forces, would cover the border with China. "Russian simple peasants from among immigrants are well aware of all the importance of populating border zones, and understand that this is a matter of state importance," he wrote, clearly showing his perception of a great difference between ethnic Russians and Kazakhs in their consciousness of belonging to the Russian state. ${ }^{59}$

Troinitskii sometimes openly expressed his prejudice against Kazakhs, asserting, for example, "Kazakhs are terribly cunning, deceitful, imbued with the spirit of litigiousness, slander, perjury and false reports. No oath they make can impel them to tell the truth." 60 This prejudice was combined with anxiety about the difficulty of grasping the situation in the local society and the possibility of subversion of power. He wrote, "There is no power in localities. Kazakhs are getting impudent, feeling themselves as full masters of the steppe, stealing cattle and horses from Russians, and even making attacks on officials." ${ }_{11}$

Troinitskii also expressed this anxiety in his letter to governor-general Shmit when he objected to Aqbaev's return to Qarqaraly, arguing that the police could not keep watch on all the Kazakhs' propaganda activities: "What is being done in the steppe, what they say and what they are plotting is completely unknown to me because of the shortage, or 
rather absence of police." ${ }^{12}$ Troinitskii and other high officials in the Steppe oblasts repeatedly requested the central government to increase the police and administrative personnel ${ }^{63}$ but the increase was slow. Troinitskii's lack of confidence in his own governing ability seems to have strengthened his attitude to crack down on every more or less suspicious person.

At the same time, he thought it desirable to settle Kazakhs and introduce to them the same administrative and judicial systems as Russians. This policy was not based on egalitarianism but aimed at eliminating "savage customs" and institutions such as the customary law courts, which the Russian government had earlier established taking Kazakh specificities into consideration. He wrote,

The nomadic Kazakh people rank below settled people in legal development, and [...

] if the settled Russian population does not have the right to be tried at its own

elective courts for various offenses and crimes, then this right should by no means

be given to the nomadic population,

[...]

the state cannot give the conquered people more rights than to the indigenous population of the state. ${ }^{64}$

He boasted that he first made knowledge of spoken Russian a requisite for candidates for volost management, emphasizing,

I could not let the main Kazakh representatives of authority, two centuries standing

under Russian rule, be ignorant of the state language. ${ }^{65}$

As reasonable as this proposition may have been, it could not alleviate Troinitskii's anxiety about the difficulty to know what the Kazakhs said among themselves as long as Russian officials did not understand Kazakh. ${ }^{66}$

Aside from Troinitskii's views expressed in official documents, we can hear his candid voice in his personal letters to his parents (in most cases, father, who was then a senator and the chairman of the statistical council at the Ministry of the Interior), kept in the Russian State Historical Archives (RGIA) in St. Petersburg. In the letters beginning with "Dear Papa," or "Dear Mama," and ending with "The son who loves you," he repeated, "I struggle like a squirrel in a wheel," "I don't see help from anyone," and "I have to work all alone" despite a tremendous amount of work, because of his subordinates' laziness. He especially vilified Vice-Governor Abaza ("an idle bastard," "busy with love affairs and office intrigues"), ${ }^{67}$ whom he repeatedly attempted to transfer outside the oblast. ${ }^{68}$ In his memoirs, Konshin states that Abaza investigated misdeeds by police officers working closely with the governor. Thus, what likely motivated Troinitskii's hatred for Abaza was not so much the vice-governor's laziness as the fact that his investigation threatened to undermine Troinitskii's position.

Troinitskii was also discontent with his superior Shmit and the Governor-Generalship of the Steppe, which "terribly hinders the development of [our oblast]. It brings no benefit but slows down and stops all affairs." The view of governor-generalships as an unnecessary administrative layer between the central government and the provinces (or oblasts) was widespread in the late tsarist period, and the Governor-Generalship of the Steppe, composed of only two oblasts (Aqmola and Semipalatinsk) after Semirech'e was transferred to the Turkestan Governor-Generalship in 1899, was especially vulnerable to criticism. Many Russian officials and Kazakh intellectuals would have sympathized with Troinitskii when he complained in January 1910, "I had to write a lot of papers for him [the governor-general], to tell the truth, against myself, to show the raison d'être of his governor-generalship." ${ }^{69}$ However, his sentiment contradicted the position of the 
ministry he belonged to: while the Ministry of the Interior under Dmitrii Sipiagin (1900-1902) argued for abolishing the Governor-Generalship of the Steppe, the ministry under Stolypin (1906-1911), who preferred decentralization of state administration, advocated its preservation and opposed deputies at the State Duma who began discussing its abolishment in $1908 .{ }^{70}$ Therefore, Troinitskii must have actually done the paperwork about the governor-generalship's raison d'être not only for Shmit but also for the ministry.

In addition, Troinitskii seemed to have a personal contempt and dislike for Shmit, despite both being rightists close to the Black Hundreds. ${ }^{71}$ Accompanying the governor-general in inspection tours upset him: "For two days I had to listen to all sorts of nasty things, so I was compelled to stop him rather sharply." Moreover, a traditional pattern of civilian-military conflict could be observed in the relations between the two. When in 1913 an attempt of invasion of the Chinese territory by a Cossack unit failed and the Russian army had to dispatch troops through slush to confront Chinese cavalry on the border, Troinitskii complained to his father,

If they had attached importance to my reports [about the necessity to strengthen the garrison in Zaysan uezd] in due time, there should not have been such a stupid situation, but the military cannot bear civilians to touch on military issues. ${ }^{72}$

His letters also reveal his prejudices against various groups of people. He wrote, "Cossacks are terribly lazy. All the Irtysh [River] belongs to them, but they even feel tiring to catch fish." ${ }^{73} \mathrm{He}$ boastfully depicted his diplomatic discourtesy and contempt for foreign cultures when a former Chinese governor-general visited him in July 1912.

Yesterday a Chinese dignitary came to me and brought gifts - five fox pelts, in addition to different small items, for instance, Egyptian cigarettes. He was very surprised when I flatly refused to receive the pelts. I had to make gifts also for the small items. How savage their customs are. When I paid a return visit and brought him my gifts, he served me excellent tea but put there marmalade with his own fingers, so I had to ask another cup, saying that the doctor has forbidden me to drink sweet tea. ${ }^{74}$

For Troinitskii, who was dissatisfied by everything in Semipalatinsk, including even hot weather, ${ }^{75}$ the dream was to be transferred to central Russia. As early as September 1909, one and a half year after his appointment, he wrote to his father,

Since I have to fight with the shortage of laborious people, sometimes appears to me a thought, isn't it better to abandon this savage land and ask for [a transfer to] European Russia. [...] It is high time for me to be closer to you. ${ }^{76}$

In August 1910, on the eve of the visit of Prime Minister Stolypin and the head of the Main Administration of Land Management and Agriculture, Aleksandr Krivoshein, ${ }^{77}$ he wrote to his father,

Here I have done more than my predecessors did for twenty years or more. [...] if there is an opportunity, I will ask Stolypin for a transfer closer to you. I have been in Siberia already for nine years, and I think that working in such an intense manner, I have a right to a transfer. ${ }^{78}$

But he was not successful then, and had to write to his mother in June 1912, "I hope I can move somewhere closer to you in winter, although there is scant hope on [Minister of the Interior Aleksandr] Makarov. Possibly Krivoshein will help." 79

An article published in the Moscow newspaper Russkoe slovo after Troinitskii's transfer also hints at how he had tried to ingratiate himself with officials from the center. According to the article, despite strange information that Konshin and others had sent to 
Stolypin's government about Troinitskii's unlawful police operations and oppression of Kazakhs, "Petersburg officials, occasionally stopping at Semipalatinsk for inspection, on their return spoke about the Semipalatinsk governor as the nicest of persons, far from politics and retaining all the freshness of youthful views." ${ }^{\text {80 }}$

Overall, Troinitskii's reports and letters suggest that his relentless and aggressive attitude to Kazakh intellectuals was related to his dissatisfaction with his own circumstances, his contempt and lack of understanding of different peoples and cultures, and his anxiety about insufficient penetration of administrative and police power into local society. It is possible that he wanted his oppression of politically active people to appear as an achievement meriting his transfer to European Russia. He was a despotic administrator, but of a totally different type from patriarchic rulers such as Kaufman and Gerasim Kolpakovskii, the first governor-general of the Steppe (1882-1889). Troinitskii lacked charisma, had no affection for the land he governed, did not paternalistically care for the people, and relied on bureaucracy and coercion.

\section{Troinitskii's impact on the Kazakh national movement}

Information about Troinitskii's persecution of innocent people and lack of understanding of culture and education gradually became known to the public in the capital. In addition to the above-mentioned efforts by Skalozubov and Konshin to draw attention of the government, the St. Petersburg newspaper V mire musul'manstvo in 1911 reported his ban on meetings of Semipalatinsk Muslims on elementary education, his refusal to approve the statute of a Muslim society for enlightenment, and the abolishment of scholarships for Kazakh students. ${ }^{81}$ Nevertheless, he was never punished by the tsarist authorities and his career was not fundamentally damaged.

51 In early 1914, at last, Troinitskii was appointed as governor of Tula province in central Russia. This was not only the realization of his longtime wish (although his father, to whom he hoped to live close, had died the previous year), but also was long-awaited good news for people in Semipalatinsk oblast. The above-mentioned article in Russkoe slovo reported that Kazakhs, who had put the blame on Troinitskii for misfortunes including even the terrible jŭt (massive death of cattle due to harsh weather in winter) in 1911-1912, were so delighted by his departure that they sacrificed 600 sheep to God. ${ }^{82}$

Troinitskii's repression of Kazakh intellectuals was excessive even by the standards of the Russian Empire, but it surely was a product of its generally oppressive system and official mind. ${ }^{83}$ On the examples examined in this paper, we can point out the following characteristics of Russian rule and interaction between imperial power and its Kazakh subjects. First, the repression was partly a result of the governors' lack of confidence in the strength of their own rule, as they had to administer the vast Kazakh steppe and its mobile nomadic population with a handful police and administrative personnel, many of whom lacked proper knowledge about local society and were involved in corruption. The arrest of dubious people, even when there was no trustworthy evidence, was a preemptive measure against destabilization. Second, there were networks of secret informers including Kazakh officials and Tatar interpreters, who provided information useful to the authorities, at the same time trapping their personal enemies. Third, there were specific bureaucrats who were especially fond of repressive measures, although the central government had mechanisms to control them to some extent. Fourth, the oppressed intellectuals did not remain passive: they knew well how the Russian 
bureaucracy worked, and actively petitioned the Ministry of the Interior, the governor-general of the Steppe, and deputies of the State Duma to release them or return them from exile.

Ultimately, the repression of Kazakh intellectuals did not stop their social and political activities. They were banished to cities adjacent to the Steppe region, where they worked with Russian and Tatar political activists, maintaining contacts with the Kazakh population and engaging in literary and journalistic activities. Orenburg, where Baytŭrsïnov and Dulatov lived, was the capital of Torghay oblast, connected with both Tashkent and the Volga region by railroads, and where the influential Tatar newspaper Waqt and magazine Shūrā were published; Qapal, where Aqbaev and Tögísov were banished, was a focal point of traffic between Vernyi (Almaty) and Semipalatinsk, and the Kazakh modern Islamic school "Māmānīya" functioned there; Troitsk, where Aqbaev lived during his second exile, was a city with a significant Tatar population and the famous modern Islamic school "Rasūlīya," and where the Kazakh magazine Ay-qap was published..$^{84}$

With regard to the effects of oppression, Baytŭrsïnov wrote a highly suggestive article in 1914, right after Troinitskii's transfer from Semipalatinsk. According to him, Troinitskii always reminded Kazakhs of their identity, saying, "You are a Kazakh, we are Russians, do not forget it." Oppression at the hand of governors like Troinitskii and Strakhovskii (governor of Torghay oblast between 1908 and 1910) rendered the Kazakhs watchful, tough and vigorous. He further wrote :

I myself have nothing to express to Troinitskii other than gratitude. Because if he were not a man who esteems and values false slander and secret denunciation, there would have been no secret denunciation of me. If there had not been secret denunciation, I would not have been deported from Qarqaraly to Orenburg. If I had not been deported to Orenburg, I would have remained in Qarqaraly and could not have done the work I do now. I deem the work I am doing for all the six million Kazakhs more important than lessons given to only fifty to sixty children. ${ }^{85}$

The work "for all the six million Kazakhs" means publication of Qazaq, an enormously influential newspaper edited by Baytŭrsïnov with the assistance of Dulatov in Orenburg and distributed to every corner of the Kazakh Steppe. The newspaper published articles discussing problems of land, local administration, military, religious, and international affairs, and also significantly contributed to the development of the Kazakh literature and language. ${ }^{86}$ It shaped the ideas and human relations that formed the basis of the political and social movement in the period of the revolutions of 1917 and the subsequent civil war. Baytŭrsïnov, Dulatov, Aqbaev and other formerly oppressed intellectuals became leaders of the Alash Orda autonomous movement between 1917 and 1920 ${ }^{87}$ while Tögísov established his own party, Üsh Jüz, in opposition to the Alash Orda. Thus, paradoxically, Governor Troinitskii stimulated the development of the Kazakh national movement. 


\section{NOTES}

1. * A shorter Japanese version was published as Tomohiko Uyama, "Semiparachinsuku shū chiji Toroinitsukī to Kazafu chishikijin dan'atsu: Teikoku tōchi ni okeru zokujin teki yōso [Semipalatinsk oblast governor Troinitskii and repression of Kazakh intellectuals: Personal factors in imperial rule]," in Takeshi Nakashima, ed., Shin shiryō de yomu Roshia shi [Reading Russian history with new materials] (Tokyo : Yamakawa shuppansha, 2013), 74-91. I am grateful to Prof. Katsunori Nishiyama, who made valuable comments on the manuscript of the Japanese version, which proved extremely useful for writing this enlarged English version.

1."Obshchee Uchrezhdenie Gubernskoe [General act for the establishment of provinces]," Articles 204, 208, 270, in Svod zakonov Rossiiskoi imperii [Collected laws of the Russian Empire], $2^{\text {nd }}$ ed., kniga 1 (SPb. : Zakonovedenie, 1913), 617-618, 626.

2. David Mackenzie, "Kaufman of Turkestan : An assessment of his administration, 1867-1881," Slavic Review 26, 2 (1967) : 265-285.

3. By "intellectuals" we mean more or less educated, and politically and/or socially active people. They included people of various professions, such as teachers, lawyers, engineers, medical doctors, clerks, interpreters, journalists, poets, men of religion, and others.

4. The repression of Kazakh intellectuals in this period is known to researchers, and Mämbet Qoygeldiev has mentioned Troinitskii's role in it, but no one has analyzed his words and behavior in detail. Mämbet Qoygeldiev, Alash qozghalïsï [The Alash movement] (Almaty: Sanat, 1995), 126-140.

5. Bol'shaia sovetskaia entsiklopediia, 2nd ed. (M. : Bol'shaia Sovetskaia Entsiklopediia, 1956), 276-277.

6. Don Karl Rowney, "Organizational change and social adaptation: The pre-revolutionary Ministry of Internal Affairs," in Walter McKenzie Pintner and Don Karl Rowney, eds., Russian officialdom: The bureaucratization of Russian society from the seventeenth to the twentieth century (London : Macmillan Press, 1980), 305, 312 ; idem, "Imperial Russian officialdom during modernization," in Don K. Rowney and Eugene Huskey, eds., Russian bureaucracy and the state : Officialdom from Alexander III to Vladimir Putin (Basingstoke : Palgrave Macmillan, 2009), 31, 36.

7. Konstantin Strukov, "Smetënnyi vikhrem revoliutsii [Swept away by the whirlwind of revolution]," Gorodskaia gazeta Tula, April 24, 2014.

8. Gubernii Rossiiskoi imperii : Istoriia i rukovoditeli, 1708-1917 [Provinces of the Russian Empire : their history and leaders, 1708-1917] (M. : Ob"edinënnaia redaktsiia MVD Rossii, 2003), $448,459$.

9. "Polozhenie ob upravlenii oblastei Akmolinskoi, Semipalatinskoi, Semirechenskoi, Ural'skoi i Turgaiskoi [Statute for the administration of Aqmola, Semipalatinsk, Semirech'e, Ural'sk, and Torghay oblasts]," note to Article 14, in Svod zakonov Rossiiskoi imperii, kniga 1, p. 1165. In Torghay oblast, Ivan Strakhovskii also became the first civilian governor in 1908; in Aqmola oblast, the first civilian governor Vladimir Losevskii was appointed in 1906, before the amendment of the statute. Gubernii Rossiiskoi imperii, 455, 460. In Semirech'e and Ural'sk oblasts, where Cossack hosts were located, military governors continued to exist, serving concurrently as Cossack head commanders (atamans).

10. Tomohiko Uyama, "A strategic alliance between Kazakh intellectuals and Russian administrators : Imagined communities in Dala Walayatïnïng Gazetí (1888-1902)," in Tadayuki Hayashi, ed., The Construction and Deconstruction of National Histories in Slavic Eurasia (Sapporo : Slavic Research Center, 2003), 237-259. 
11. Alash qozghalïsï / Dvizhenie Alash : Sbornik dokumentov, vol. 1 (Almaty : Alash, 2004), 33-39. 12. Kazan Provisional Committee on the Press, a major censorship organ for publications in Oriental languages, received 16 books in Kazakh in 1909, 25 in 1910, and 80 in 1911. Zhumagyz Shalgynbai, ed., Kazakhskoe knizhnoe delo v dokumentakh i materialakh (XIX-nachalo XX) : Sbornik arkhivnykh dokumentov [Kazakh book publishing in documents and materials (the 19th and early 20th centuries) : collection of archival documents] (Almaty: Baspalar üyí, 2009), 408-410, 479-480.

13. Zarqïn Tayshïbay and Nŭrlan Dulatbekov, Jaqïp Aqbaev: Küreskerlík ömírbayanï [Yaqub Aqbaev : Biography of a fighter] (Almaty : Jetí jarghï, 1997), 8-29 ; Alikhan Bukeikhanov, "Vybory v Stepnom krae [Elections in the Steppe region]," in K 10-letiiu 1-oi Gosudarstvennoi Dumy : Sbornik statei pervodumtsev [Commemorating the 10th anniversary of the First State Duma : collection of essays by the first deputies] (Pg. : Ogni, 1916), 44-45 ; TsGA RK (Central State Archive of the Republic of Kazakhstan), f. 64, op. 1, d. 5832, 1. 150-151.

14. Evgenii Ottovich Shmit (1844-1915) was a general of the cavalry with no previous administrative career. After working as assistant commander of the Kiev Military District (1906-1908), he became governor-general of the Steppe, commander of the Omsk Military District, and ataman of the Siberian Cossack Host, concurrently (1908-1915). Russkaia armiia v Velikoi voine : Kartoteka proekta [The Russian Army in the Great War : card index of the project] http://www.grwar.ru/persons/persons.html?id=2126

15. TsGA RK, f. 64, op. 1, d. 5832, 1. 1-17 ; f. 369, op. 1, d. 1005, 1. 13.

16. For more about Pahlen's inspection, see Alexander Morrison, "'Sowing the seed of national strife in this alien region': The Pahlen report and pereselenie in Turkestan, 1908-1910," Acta Slavica Iaponica, 31 (2012) : 1-29.

17. Aqbaev's petition to Pahlen, TsGA RK, f. 64, op. 1, d.5832, 1.150-186. This petition has been published in Mukhtar Kul-Mukhammed, Zhakyp Akpaev: Patriot, politik, pravoved [Yaqub Aqbaev : patriot, politician, and jurist] (Almaty : Atamŭra, 1995), 186-232.

18. The statute for the administration of the Steppe oblasts gave uezd chiefs the right to appoint the time and place for a volost conference to elect a volost head, and to present the name of the elected head to the governor for approval, attaching his own judgment. With the introduction of the institution of peasant captains in 1902, these competences were transferred to the latter. "Polozhenie ob upravlenii oblastei," note to Article 33, and Articles 67, 69, Svod zakonov Rossiiskoi imperii, kniga 1, 1169, 1174.

19. Troinitskii fired Tsylov in July 1908 after the latter was beaten by Kazakhs for violations in the election of a village head and for unlawful arrests. G.S. Sultangalieva, "Krest'ianskie nachal 'niki i kazakhskoe naselenie: kharakter vzaimodeistviia [Peasant captains and the Kazakh population : the character of interaction]," Vestnik KazNU, Seriia istoricheskaia, no. 4 (2010) : 33. Aqbaev considered this dismissal a result of his complaint to the governor. TsGA RK, f. 64, op. 1, d. 5832, 1. 165ob.-166ob.

20. Aleksandr Semënovich Galkin (1855-1920) had rich experience in working in Central Asia, and held various positions in Omsk and Turkestan military districts before becoming Semipalatinsk military governor (1903-1908). Later he was appointed governor of Samarkand (1908-1911) and Syrdarya (1911-1916) provinces. Russkaia armiia v Velikoi voine: Kartoteka proekta <http:// www.grwar.ru/persons/persons.html?id=2672>. We will examine Galkin's character further down.

21. TsGA RK, f. 64, op. 1, d. 5832, 1. 187-204.

22. TsGA RK, f. 64 , op. 1 , d. 5832, 1. 13-16.

23. TsGA RK, f. 369, op. 1, d.1005, 1. 9. In this and other Russian sources, Kazakhs are called kirgizy, a misnomer used in Russian from the eighteenth century to 1925.

24. TsGA RK, f. 64, op. 1, d. 5832, 1. 28-41.

25. TsGA RK, f. 369, op. 1, d. 1005, 1. 19. 
26. TsGA RK, f. 64 , op. 1 , d. $5832,1.83$.

27. TsGA RK, f. 64, op. 1, d. 5832, 1. 232.

28. TsGA RK, f. 64, op. 1, d. 5832, 1. 47-56.

29. Skalozubov was a nonpartisan deputy of the Second and Third State Dumas from Tobol'sk province. Earlier, he worked as provincial agronomist and participated in the Tobol'sk provincial committee on the needs of agricultural industry (see below), and met Troinitskii there.

30. TsGA RK, f. 64, op. 1, d. 5832, 1. 58-61.

31. TsGA RK, f. 64 , op. 1 , d. 5927, 1. 5, 19-20.

32. TsGA RK, f. 64, op. 1, d. 5927, 1. 21-25, 38-41.

33. TsGA RK, f. 64 , op. 1, d. 5927, 1. 44-57.

34. TsGA RK, f. 64, op. 1, d. 5927, 1. 64-64ob., 68-68ob.

35. Mir-Ya'qub Dulatov, Oyan, qazaq! (Ufa : Sharq, 1910). About this book, see Tomohiko Uyama, "The Kazak intelligentsia at the crossroads of three civilizations," in Timur Kocaoglu, ed., Reform movements and revolutions in Turkistan (1900-1924): Studies in honour of Osman Khoja (Haarlem : SOTA, 2001), 396-399.

36. Shalgynbai, Kazakhskoe knizhnoe delo, 430-431. Levanevskii began to work in Semipalatinsk oblast earlier than Troinitskii and played an important role in the repression of political activists there during and after the Revolution of 1905, but details of his biography are unknown.

37. This constituted Troinitskii's another accusation against the Governor-Generalship of the Steppe.

38. TsGA RK, f. 15, op. 2, d. 408, 1.12-19. The Kazan Provisional Committee on the Press did not find Awake, Kazakh ! criminal when it first examined the book in March 1911, but after Dulatov's arrest, the committee banned the book in November after its reexamination by the famous Turkologist Nikolai Katanov, an ethnic Khakas. Shalgynbai, Kazakhskoe knizhnoe delo, 453.

39. Marat Äbsemet, Mírjaqïp (ömírí men shïgharmashïlïghï) [Mir-Yaqub : his life and work] (Almaty : KENJE-Press, 1995), 21-28.

40. Jane Burbank, "An imperial rights regime: Law and citizenship in the Russian Empire," Kritika : Explorations in Russian and Eurasian history 7, 3 (2006) : 417.

41. There are a number of studies on petitions and denunciations in Russia and the Soviet Union. E.g., Gregory L. Freeze, From supplication to revolution: A documentary social history of Imperial Russia (New York: Oxford University Press, 1988); Sheila Fitzpatrick, Tear off the masks! Identity and imposture in twentieth-century Russia (Princeton: Princeton University Press), ch. 9, "Supplicants and citizens." About how Muslims in the Russian Empire petitioned the authorities, see Robert D. Crews, For prophet and tsar: Islam and empire in Russia and Central Asia (Cambridge, MA : Harvard University Press, 2006) ; Paolo Sartori, "Behind a petition : Why Muslims' appeals increased in Turkestan under Russian Rule," Asiatische Studien/Études asiatiques 63, 2 (2009) : 401-434.

42. AP RK (Archive of the President of the Republic of Kazakhstan), f. 811, op. 3, d. 46, 1. 1ob., 3, 9, 12ob., 14-17ob.

43. N.S. Trusova et al., eds., Revoliutsiia 1905-1907 gg. v Rossii : dokumenty i materialy, Vtoroi period revoliutsii, 1906-1907 gody (ianvar'-iiun' 1907 goda) [The revolution of 1905-1907 in Russia : documents and materials, the second period of the revolution, 1906-1907 (January-June, 1907)], kniga 2 (M. : Nauka, 1965), 173-174.

44. A.V. Piaskovskii et al., eds., Vosstanie 1916 goda v Srednei Azii i Kazakhstane: Sbornik dokumentov [The revolt of 1916 in Central Asia and Kazakhstan : collection of documents] (M. : Izd-vo AN SSSR, 1960), 273-274, 728-729 ; "Vosstanie 1916 g. v Srednei Azii [The revolt of 1916 in Central Asia]," Krasnyi arkhiv, 34 (1929) : 51.

45. About Troinitskii's oppressive censorship and attempts at imposing his bizarre view of life (in the words of the publisher of a newspaper) on the press in Tobol'sk province, see E.N. Konovalova, Kniga Tobol'skoi gubernii, 1790-1917 gg. : svodnyi katalog mestnykh izdanii 
[Books in Tobol'sk province, 1790-1917: general catalog of local publications] (Novosibirsk: GPNTB SO RAN, 2006), 65-66, 73. (Konovalova mistakenly writes Troinitskii's initials as "V.A.," confusing him with his uncle, Vladimir Aleksandrovich, who worked as Tobol'sk governor from 1886 to 1892 .)

46. AP RK, f. 811, op. 3, d. 46, 1. 9ob.-12, 17ob.-24.

47. Uyama, "A Strategic Alliance," 247 ; A.S. Morrison, Russian rule in Samarkand 1868-1910 : A Comparison with British India (Oxford : Oxford University Press, 2008), 182-193.

48. "Vremennoe Polozhenie o Krest'ianskikh Nachal'nikakh [Provisional statute on peasant captains]," in Svod zakonov Rossiiskoi imperii, 2nd ed., kniga 2 (SPb., 1913), 2244-2264; V.N. Nikulin, "Krest'ianskie nachal'niki v Sibiri (1898-1917 gg.) [Peasant captains in Siberia (1898-1917)]," Voprosy istorii, no. 1 (1987) : 170-175 ; L.M. Dameshek and A.V. Remnev, eds., Sibir' $\mathrm{v}$ sostave Rossiiskoi imperii [Siberia as part of the Russian Empire] (M.: Novoe literaturnoe obozrenie, 2007), 235-243.

49. TsGA RK, f. 64, op. 1, d. 125, 1. 338-339ob., 353-354, 373-376.

50. Nikulin, “Krest'ianskie nachal'niki," 172.

51. TsGA RK, f. 64, op. 1, d. 125, 1.338ob.

52. TsGA RK, f. 64, op. 1, d. 5832, l. 170.

53. Trudy mestnykh komitetov o nuzhdakh sel'skokhoziaistvennoi promyshlennosti [Proceedings of the local committees on the needs of agriculture], vol. 53, Tobol'skaia guberniia [Tobol'sk province] (SPb. : Tipografiia V.F. Kirshbauma, 1903), 50-55, 57-61, 270-272.

54. A.A. Kaufman, ed., Svod trudov mestnykh komitetov po Kavkazu, Oblasti Voiska Donskogo, Sibiri, Stepnomu kraiu i Turkestanu [Digest of the proceedings of the local committees of the Caucasus, the Don Host Oblast, Siberia, the Steppe region, and Turkestan] (SPb.: Tipografiia V.F. Kirshbauma, 1904), 603-610, 619-620, 638-645.

55. Temporary governor-generals were appointed in emergency to suppress revolutionary disorders and did not necessarily have jurisdiction over vast regions like ordinary governor-generals. V.V. Cherkesov, ed., Institut general-gubernatorstva i namestnichestva v Rossiiskoi imperii [Institution of governor-generalships and viceroyalties in the Russian Empire], vol. 1 (SPb. : Izd-vo S. Peterb. un-ta, 2001), 248-251.

56. Like Troinitskii, Gondatti was a rightist official who would become the first civilian to serve as Priamur governor-general (1911-1917). Relations between the two are still to be studied.

57. D.I. Kopylov et al., eds., Revoliutsionnoe dvizhenie v Tobol'skoi gubernii v 1905-1914 gg. : Sbornik dokumentov [The revolutionary movement in Tobol'sk province in 1905-1914: collection of documents] (Sverdlovsk : Sredne-Ural'skoe knizhnoe izd-vo, 1981), 38, 54-55, 57, 59, 62, 66, 94 ; V.V. Konovalov, ed., Sibirskie i tobol'skie gubernatory: istoricheskie portrety, dokumenty [Siberian and Tobol'sk governors: historical portraits and documents] (Tyumen: Tiumenskii izdatel'skii dom, 2000), 404-405, 422, 424.

58. Bökeykhanov wrote that during this war many Kazakhs believed that the Japanese were Muslims and relatives of the Kazakhs, which was allegedly testified by the physical similarity of the two peoples. A. Bukeikhanov, "Kirgizy," in A.I. Kastelianskii, ed., Formy natsional'nogo dvizheniia v sovremennykh gosudarstvakh: Avstro-Vengriia, Rossiia, Germaniia [Forms of national movement in modern states: Austria-Hungary, Russia, Germany] (SPb. : Obshchestvennaia Pol'za, 1910), 596. Dulatov wrote a poem in which he compared the tsar to a brutal lion who tormented smaller animals (i.e., minorities) but was defeated by shortish and energetic animals living elsewhere (i.e., Japan), united under just law. Dulatov, Oyan, qazaq! 60-64.

59. Report to the emperor about the situation in Semipalatinsk oblast for 1908. RGIA (Russian State Historical Archive), f. Biblioteka, op. 1, d. 85, 1. 118-118ob.

60. Report to the emperor about the situation in Semipalatinsk oblast for 1910. RGIA, f. Biblioteka, op. 1, d. 85, 1. 131. 
61. Ibid., 1. 130.

62. TsGA RK, f. 64, op. 1, d. 5832, 1. 33ob.

63. E.g., Aqmola Governor Vladimir Losevskii proposed in 1908 and 1909 to establish positions of field police officers (stanovoi pristav) and paramilitary police guards of uezds (uezdnaia politseiskaia strazha). F.N. Kireev and F.I. Kolodin, eds., Rabochee i agrarnoe dvizhenie v Kazakhstane v 1907-1914 godakh: Sbornik dokumentov i materialov [Labor and agrarian movements in Kazakhstan in 1907-1914 : collection of documents and materials] (Alma-Ata : Kazakhskoe gos. izd-vo, 1957), 191-193. Shortage of manpower in administration and police was a problem common to Turkestan. Morrison, Russian rule in Samarkand, 131.

64. Report to the emperor about the situation in Semipalatinsk oblast for 1910. RGIA, f. Biblioteka, op. 1, d. 85, 1.131-132. Many Kazakh intellectuals also recognized the dysfunction and corruption of customary law courts, but saw their causes in the elections of judges and other systems introduced by Russia as well as changes in Kazakh society, and sought their reform rather than abolition. Tomohiko Uyama, "Vzgliady kazakhskoi intelligentsii na sud biev, russkii sud i shariat (konets XIX - nachalo XX vv.) [Kazakh intellectuals' views on biys' court, Russian court, and Sharia (the late 19th and early 20th centuries)]," in Drevnii mir prava kazakhov: materialy, dokumenty i issledovaniia $\mathrm{v}$ desiati tomakh [The ancient world of the Kazakh law : materials, documents, and researches in ten volumes], vol. 10 (Almaty : Jetí jarghï, 2009), 296-301. 65. Report to the emperor about the situation in Semipalatinsk oblast for 1910. RGIA, f. Biblioteka, op. 1, d. 85, 1. 131. See Troinitskii's circular order in 1909 to peasant captains on this issue in Kireev and Kolodin, Rabochee i agrarnoe dvizhenie, 173.

66. Unlike Turkestan, where the military bureaucracy (although often ineffectively) encouraged Russian officers to learn local languages, and a number of uezd chiefs were versed in Turki and Persian (Morrison, Russian rule in Samarkand, 147-151, 163), there is no indication that the administrations of the Steppe oblasts tried to systematically train Russian officials in the Kazakh language. Bökeykhanov cites a senior clerk at the chancellery of the governor-general of the Steppe saying, "The Kazakhs themselves must rise up to [the level of] us ; we do not have to learn their language !" Bukeikhanov, "Kirgizy," 585.

67. Troinitskii seems to have been fond of abusive language. In 1912, peasants wrote a complaint addressed to the empress and the minister of the Interior that when he visited their village, "the governor at first sight felt free to abuse all of us with vulgar foul language [materit' ploshchadnoi bran'iu]. Moreover, he threatened us with imprisonment and dispersing all to hungry steppes and sands." Kireev and Kolodin, Rabochee i agrarnoe dvizhenie, 412-413.

68. RGIA, f. 1065, op. 1, d. 57, 1.9-9ob., 13ob., 48, 54-54ob., 60, 305-305ob. Abaza served as vice-governor of Semipalatinsk oblast from January 1907 to June 1911. Gubernii Rossiiskoi imperii, 460.

69. RGIA, f. 1065, op. 1, d. 57, 1. 530b.-54, 257ob.-258. For a Kazakh intellectual's opinion about the superfluousness of the Governor-Generalship of the Steppe, see V. [ =Älikhan Bökeykhanov], "Nenuzhnoe general-gubernatorstvo [Unnecessary governor-generalship]," Sibirskie voprosy, nos. 45-46 (1908) : 6-10.

70. A.V. Remnev, "Stepnoe general-gubernatorstvo $\mathrm{v}$ imperskoi geografii vlasti [The Governor-Generalship of the Steppe in the imperial geography of power]," in N.G. Suvorova, ed., Aziatskaia Rossiia : liudi i struktury imperii : sbornik nauchnykh statei [Asiatic Russia : people and the structure of the empire : collection of scholarly articles] (Omsk: Izd-vo OmGU, 2005), 206-219. The State Duma finally passed the bill to abolish the Governor-Generalships of the Steppe and Kiev in 1912, but the State Council rejected it. Gosudarstvennaia Duma, Tretii sozyv : Stenograficheskie otchety, 1912 g., Sessiia piataia, chast' IV [State Duma, the third convocation : stenographic reports, 1912, the fifth session, part 4] (SPb.: Gos. tipografiia, 1912), 2281-2284, $3525-3528,4336$. 
71. TsGA RK, f. 64 , op. 1 , d.5832, 1.185ob.-186; Kireev and Kolodin, Rabochee i agrarnoe dvizhenie, 210-211 ; AP RK, f. 811, op. 3, d. 46, 1. 9ob.

72. RGIA, f. 1065, op. 1, d. 57, 1. 162-162ob., 177, 189ob.-190ob.

73. RGIA, f. 1065 , op. 1, d. 57, 1. 257ob.

74. RGIA, f. 1065, op. 1, d. 57, 1. 239-239ob.

75. RGIA, f. 1065, op. 1, d. 57, 1. 53-53ob., 234ob.

76. RGIA, f. 1065, op. 1, d. 57, 1. 69-69ob.

77. Stolypin and Krivoshein toured about Siberia to inspect the situation of peasant resettlement. Krivoshein was an influential politician nicknamed "Minister of Asiatic Russia" for his zeal in settling Russian peasants in Siberia, the Russian Far East, and Central Asia. Willard Sunderland, "The Ministry of Asiatic Russia : The colonial office that never was but might have been," Slavic Review, 69, 1 (2010) : 145-149.

78. RGIA, f. 1065 , op. 1 , d. 57, 1. 55ob.-56.

79. RGIA, f. 1065, op. 1, d. 57, 1. 233.

80. Villi, "V ekzoticheskoi strane [In an exotic country]," Russkoe slovo, March 1, 1914 (TsGA RK, f. 64, op. 1, d. 5832, 1. 206).

81. V mire musul'manstva, May 6, 1911.

82. Troinitskii worked as Tula governor until he was arrested in March 1917 by revolutionary workers and soldiers. Information about his further fate is scant and contradictory, but according to some sources, he was repeatedly arrested by the Soviets and banished to various places in Russia up until the 1930s. Zakleimennye vlast'iu [Stigmatized by power] <http:// pkk.memo.ru/page\%202/KNIGA/To.html>.

83. "Official mind" is a concept coined by Ronald Robinson and John Gallagher in their Africa and the Victorians: The official mind of imperialism (London: Macmillan, 1961) to designate the collective mind of policy-makers of the British Empire during its expansion. Alexander Morrison refines it as "a bundle of prejudices, assumptions, ambition, and ignorance, generally with very imperfect access to information, deeply affected by rumour, often reacting wildly and erratically to the pressure of 'events', and with multiple different identities and perspectives." Alexander Morrison, "Twin imperial disasters: The invasions of Khiva and Afghanistan in the Russian and British official mind, 1839-1842," Modern Asian Studies 48, 1 (2014) : 259.

84. The central part of the Kazakh Steppe was scarcely populated because of its aridity, and many of the cities and towns that could serve as bases of political, social, and cultural activities were situated on the rim of the steppe, often outside the zones where oppressed intellectuals were prohibited from living. For geographical factors in the activities of Kazakh intellectuals, see Tomohiko Uyama, "The geography of civilizations: A spatial analysis of the Kazakh intelligentsia's activities, from the mid-nineteenth to the early twentieth century," in Kimitaka Matsuzato, ed., Regions : A prism to view the Slavic-Eurasian world: Towards a discipline of "regionology" (Sapporo : Slavic Research Center, 2000), 70-99.

85. A.B. [ = Akhmet Baytŭrsïnov], "Gubernator özgeríluí” [Change of governor], Qazaq, no. 50, February 14, 1914.

86. See Ö. Äbdímanov, “Qazaq” gazetí [The newspaper Qazaq] (Almaty : Qazaqstan, 1993).

87. For more about the Alash Orda, see Qoygeldiev, Alash qozghalïï (see note 4), and Dina Amanzholova, Na izlome : Alash v etnopoliticheskoi istorii Kazakhstana [At the turn : Alash in the ethnopolitical history of Kazakhstan] (Almaty : Taimas, 2009). 


\section{ABSTRACTS}

Around 1910, a number of prominent Kazakh intellectuals were arrested in Semipalatinsk oblast. Governor Troinitskii was deeply involved in their arrests and subsequent banishments, employing the police and local informers. This article examines how the governor insisted on punishing them severely, sometimes even conflicting with his senior, the governor-general of the Steppe, and how the intellectuals petitioned the authorities to release them. It also scrutinizes Troinitskii's ideas, perceptions, prejudices, and emotions through his official reports and personal letters. The repression derived both from the governor's personality and the mindset of the Russian authorities in the Kazakh Steppe, especially their lack of confidence in the strength of their own rule. The banished intellectuals engaged in literary and journalistic activities in cities adjacent to the steppe, developing the ideas and human relations that formed the basis of the future autonomy movement. Paradoxically, the oppression by Troinitskii stimulated the development of the Kazakh national movement.

Vers 1910, un certain nombre d'éminents intellectuels kazakhs fut arrêté dans l'oblast de Semipalatinsk. Le gouverneur Trojnickij était largement impliqué dans ces arrestations et les bannissements qui s'ensuivirent, ayant recouru pour cela aux services de la police et des informateurs locaux. L'article examine comment le gouverneur insista pour que les intellectuels fussent sévèrement punis, entrant même en conflit avec son responsable hiérarchique, le gouverneur général de la Steppe, et comment les intellectuels adressèrent une pétition aux autorités pour demander leur libération. Il passe aussi en revue les idées de Trojnickij, ses perceptions, préjugés et émotions au travers de ses rapports officiels et de sa correspondance personnelle. La répression résultait tant de la personnalité du gouverneur que de l'état d'esprit des autorités russes en poste dans la Steppe kazakhe, et plus singulièrement de leur manque de confiance en la force de leur propre administration. Les intellectuels bannis s'engagèrent dans des activités littéraires et journalistiques dans des villes limitrophes de la steppe, élaborant les idées et les relations humaines qui furent à la base du futur mouvement pour l'autonomie. Paradoxalement, l'oppression exercée par Trojnickij stimula le développement du mouvement national kazakh.

\section{AUTHOR}

\section{TOMOHIKO UYAMA}

Slavic-Eurasian Research Center, Hokkaido University, uyama@slav.hokudai.ac.jp 